\title{
Effect of Urea Fertilizer and Poultry Manure on Nitrate Reductase Activity of Potato and some Tuber Composition
}

\author{
Mohammad Asefi ${ }^{1}$, Mahmud Khoramivafa ${ }^{1}{ }^{*}$, Ahmad Ismaili $^{2}$, Mohsen Saeidi ${ }^{1}$ \\ ${ }^{1}$ Department of Agronomy and Plant Breeding, Campus of Agriculture and Natural Resources, Razi University, Kermanshah, Iran \\ ${ }^{2}$ Department of Agronomy and Plant Breeding, Faculty of Agriculture, Lorestan University, Khorramabad, Iran
}

Corresponding Author: Mahmud Khoramivafa, PhD, Assistant Professor, Department of Agronomy and Plant Breeding, Campus of Agriculture and Natural Resources, Razi University, Kermanshah, Iran. Tel: +98-9122451629, Email: khoramivafa@razi.ac.ir

Received July 14, 2019; Accepted August 10, 2019; Online Published December 5, 2019

\begin{abstract}
Introduction: Nowadays, increasing environmental risks to human health have caused increasing attention to use chemical nitrogen sources efficiently or nitrogen supplying from organic amendments. In this respect, chicken manure seems to be a good alternative to chemical nitrogen fertilizers. The purpose of this experiment is to investigate the role of urea and poultry manure and ecological factors (climate) on the quantity of some chemical compositions of the potato tuber.

Materials and Methods: To study the effects of urea and poultry manure on some potato tuber compositions, the factorial experiment was conducted in 2015-2016 during the growing season in 2 regions; Azna and Khorramabad which is located in Lorestan province in the west of Iran. The factors were 2 different sources of nitrogen supply including urea fertilizer and poultry manure.

Results: Results show that the highest activity of nitrate reductase (NR) in both sites was observed using 10304 kg of poultry manure ha-1 . The results also showed that the tuber nitrate content was only affected by the fertilizer source. In both studied places, the highest tuber nitrate was associated with high levels of urea fertilizer. Based on the results, the vitamin $\mathrm{C}$ of potato tubers grown by poultry manure were also superior to the relative vitamin $\mathrm{C}$ content. According to the results of this experiment, the accumulation of more than 2 times the nitrate in the tubers was obtained from urea fertilizer (244.2 versus 100 ppm).

Conclusions: In order to achieve food security and an efficient and sustainable food chain, chemical fertilizers must be replaced with organic fertilizers. Thus, the belief that the use of organic fertilizers, at any level, would not cause any problem for the health of products is definitely incorrect.

Keywords: Human Heath, Organic Fertilizer, Nitrate Accumulation, AtNRT 1:1 gene, Vitamin C

Citation: Asefi M, Khoramivafa M, Ismaili A, Saeidi M. Effect of urea fertilizer and poultry manure on nitrate reductase activity of potato and some tuber composition. J Appl Biotechnol Rep. 2019;6(4):180-185. doi:10.29252/JABR.06.04.08.
\end{abstract}

\section{Introduction}

Increasing concerns in regards to environmental pollution along with human health risks have been resulted in paying more attention to increase nitrogen uptake efficiency or supply it through non-chemical nitrogen sources. Organic fertilizers, in contrast to mineral fertilizers, gradually release nitrogen for plant nutrition, which prevents excessive accumulation of nitrates in the tissue of plant. ${ }^{1}$

The global demand for nitrogen fertilizers is increasing day by day, so that global nitrogen consumption has increased 100 times since the past 100 years. Using high volumes of nitrogen has had severe environmental consequences as well as health damages. Perhaps one of the most prominent damages is the accumulation of nitrates in the edible organs of plants. ${ }^{2}$ However, for replacing the chemical fertilizers, a source of organic fertilizer is needed that has a good mineralization rate and also must be rich in micro and macro elements. In this respect, chicken manure seems to be a good alternative. ${ }^{3}$

There is an increasing interest in environmental protection and food quality which has resulted in a considerable expansion in the non-chemical depended farming systems in recent decades. Opposed to chemical depended farming systems, organic systems are widely identified as sustainable and consumer environment - friendly, as they specifically avoid using agrochemicals such as fertilizers and pesticides. ${ }^{4}$

Potato is one of the 140 species belonging to Solanum genus, which is referred as the hidden jewel, due to its role in eliminating global crises, such as hunger and poverty. ${ }^{5}$ Based on literature, Iran has produced close to 5 million tons of potato per year in $2016 .^{6}$

Effective fertility management is critical to profitable production of potatoes. In addition, potatoes have a relatively high water consumption (about $6500 \mathrm{~m}^{3} \mathrm{ha}^{-1}$ ) therefore supplemental Irrigation is necessary in drought regions. ${ }^{7}$ As a result, the nitrate leaching result in the contamination of groundwater with nitrate in the potato fields or its accumulation in the edible organs. ${ }^{8}$ It has been reported that $97 \%$ of nitrate entries the human body through vegetables, $32 \%$ of which is the contribution of potato consumption. ${ }^{9}$

The acceptable daily intake (ADI) of nitrate ion is $3.65 \mathrm{mg}$

Copyright (C) 2019 The Author(s). This is an open-access article distributed under the terms of the Creative Commons Attribution License (http:// creativecommons.org/licenses/by/4.0), which permits unrestricted use, distribution, and reproduction in any medium, provided the original work is properly cited. 
$\mathrm{kg}^{-1}$ body weight (equivalent to $219 \mathrm{mg} \cdot \mathrm{day}^{-1}$ for a person weighing $60 \mathrm{~kg}$ ) based on the European Commission (EC)'s and Scientific Committee for Food (SCF). ${ }^{10}$

The accumulation rate of nitrate in potato tubers, in addition to the genetic factor, is attributed to other factors such as light intensity, growth season temperature, pest and disease control methods and soil moisture. ${ }^{9,11}$ The response of a plant to nitrate accumulation is depended on nitrate reductase (NR) enzyme activity and other metabolic reactions mainly related to nitrate. Also, the NR activity is related to the amount of nitrate sensitive protein production. It is suggested that this protein is probably linked to the regulating region of the nitrogen reductase gene and the mRNA expression of the NR enzyme. ${ }^{12}$

The major sources of vitamin $\mathrm{C}$ in the human diet are fruits and vegetables. Potato is one of the most important sources of vitamin $\mathrm{C}$ in the countries which produce and consume potatoes. Any enhancement in the vitamin $\mathrm{C}$ content of potatoes results in a beneficial impact on human nutrition. ${ }^{13}$

Few studies have been conducted on the supply source of nitrogen and environmental factors on potato compositions. In this regard, the effect of nitrogen fertilizer was investigated on some chemical compositions of early potatoes. The results of this experiment showed that an increase in the nitrogen content increased the tuber yield but reduced the amount of starch and crude protein. Also, the ratio of amino acids associated with total nitrogen was decreased. In this case, the decrease in the amount of arginine amino acids, glutamine and aspartic acid was more pronounced. ${ }^{14}$ In another study, it has been shown that the rates of vitamin $\mathrm{C}$ is affected by the source of nitrogen fertilizer and the cultivation system. ${ }^{15}$

Determining the role of urea and poultry manure as well as the effects of climate and soil conditions on the amount of nitrate, vitamin C, etc. can be an important step towards improving potato market and community health. To replace or reduce the use of chemical fertilizers, a source of organic fertilizers is needed which can be quickly mineralized and also be rich in terms of micro and macro elements. In this regard, it seems that chicken manure is a good alternative to chemical fertilizers in the potato cultivation. ${ }^{3}$ However, the high consumption of organic fertilizers may also result in the accumulation of nitrate in potato tubers. ${ }^{1}$ Therefore, the purpose of this study was to investigate the role of urea and poultry manure and ecological factors (climate) on the quantity of some chemical compositions of the potato tuber. Also, the replacement or reduction of nitrogen fertilizer with chicken manure was investigated in order to determine the best value of it by maintaining the quantitative and qualitative performance of potato. However, due to excess application of nitrogen in intensive potato production systems, providing practical solutions to manage nitrogen is extremely.

\section{Materials and Methods}

The experiment was conducted as a randomized complete block design with 11 treatments on the potato of Banba cultivar (Medium - tall, an early main crop with good warehousing) in 3 replications in 2 regions (Azna and Khorramabad, located in Lorestan province, west of Iran). Each plots were $2.25 \mathrm{~m}$ wide and $2.55 \mathrm{~m}$ long including 4 rows with 75 and $17 \mathrm{~cm}$ distance between and within potato plants in rows, respectively. Tubers of 60-70 g were sown on the $10^{\text {th }}$ of March and the $4^{\text {th }}$ of June 2015 in Khorramabad and Azna respectively with $20 \mathrm{~cm}$ of sowing depth. Table 1 shows some soil physiochemical properties of soils of regions. Classical rain irrigation was applied while there was $1.5 \mathrm{~m}$ distance between adjacent plots to prevent the interference of treatment effects and run-off water was directed out of blocks by individual provided furrows.

The treatments included a control treatment $\left(\mathrm{T}_{1}\right)$ (without nitrogen application) along with ten levels of nitrogen consumption based on urea fertilizer and poultry manure sources. Urea fertilizer source levels $\left(\mathrm{T}_{2}\right.$ to $\left.\mathrm{T}_{6}\right)$ were 50, $100,150,200$, and $250 \%$ of $\mathrm{N}_{\mathrm{b}}$, which $\mathrm{N}_{\mathrm{b}}$ was the minimum amount of nitrogen requirement for potato plant according to soil analysis. Poultry manure source quantities $\left(\mathrm{T}_{7}\right.$ to $\left.\mathrm{T}_{11}\right)$ included 50,100, 150, 200 and $250 \%$ of the $\mathrm{N}_{\mathrm{b}}$.

For the analysis of poultry manure nutrient elements (Table 2 ), a sample of 10 random samples were selected and, after drying in the shade they were grinded and passed through a $2 \mathrm{~mm}$ sieve. Manure $\mathrm{pH}$ and $\mathrm{EC}$ were measured at a ratio of 1:10 (w/v). The amount of organic matter was determined by samples cremation at $550^{\circ} \mathrm{C}$. Total nitrogen was also measured by the Kjeldahl method. ${ }^{16}$ The Olsen method was used to determine the amount of phosphorus. The amount of potassium was determined using the photometric method, and zinc, copper, iron and manganese values were determined using the atomic absorption spectrometry. ${ }^{17}$

All experimental plots received urea fertilizer in 3 different plant growth stages including planting time, tuber initiation and tuber bulking. While all poultry manure was applied at the time of the land preparation. The nitrogen consumption (using urea fertilizer source) and poultry manure have been described in Table 3.

A total tuber yield was recorded from 2 intermediate

Table 1. Soil Physicochemical Analyses (Depth of $0-30 \mathrm{~cm}$ )

\begin{tabular}{|c|c|c|c|c|c|c|c|}
\hline Region & Soil Texture & $\mathrm{EC}\left(\mathrm{dS} . \mathrm{m}^{-1}\right)$ & $\mathrm{pH}$ & OC \% & OM\% & P(av.) mg.kg-1 & K(av.) mg.kg ${ }^{-1}$ \\
\hline Khorramabad & Clay Loam & 1.18 & 7.62 & 0.98 & 1.7 & 21.8 & 355 \\
\hline Azna & Loam & 0.84 & 8.44 & 0.69 & 1.19 & 27 & 371 \\
\hline
\end{tabular}

Table 2. Analysis of Utilized Poultry Manure

\begin{tabular}{|c|c|c|c|c|c|c|c|c|c|c|c|}
\hline $\mathrm{pH}$ & $\mathrm{N}(\%)$ & $\mathrm{P}_{2} \mathrm{O}_{5}(\%)$ & $\mathrm{K}_{2} \mathrm{O}(\%)$ & OC $(\%)$ & $\mathrm{N}-\mathrm{NH}_{4}\left(\mathbf{m g} \cdot \mathrm{kg}^{-1)}\right.$ & $\mathrm{N}-\mathrm{NO}_{3}\left(\mathbf{m g} \cdot \mathrm{kg}^{-1)}\right.$ & $\mathrm{Cu}\left(\mathbf{m g} \cdot \mathbf{k g}^{-1)}\right.$ & Zn (mg.kg ${ }^{-1)}$ & Mn (mg.kg ${ }^{-1)}$ & Fe (mg.kg-1) & EC $\left(\mathrm{ds} . \mathrm{m}^{-}\right)^{1}$ \\
\hline 6.6 & 4.98 & 3.69 & 2.47 & 35.8 & 5550 & 355 & 71.5 & 1475 & 520 & 1825 & 8.9 \\
\hline
\end{tabular}


Table 3. The Amounts of Urea Fertilizer and Poultry Manure Based on Soil Test Value in 2 Experimental Regions

\begin{tabular}{|c|c|c|c|c|c|c|c|c|c|c|}
\hline \multicolumn{5}{|c|}{ Poultry Manure (kg.ha-1) } & \multicolumn{6}{|c|}{ Urea Fertilizer (kg.ha-1) } \\
\hline$T_{11}$ & $T_{10}$ & $T_{9}$ & $T_{9}$ & $T_{7}$ & $T_{6}$ & $\mathbf{T}_{5}$ & $\mathrm{~T}_{4}$ & $\mathbf{T}_{3}$ & $\mathbf{T}_{2}$ & $\mathrm{~T}_{2}$ \\
\hline 12880 & 10304 & 7728 & 7728 & 2700 & 875 & 700 & 525 & 350 & 175 & 175 \\
\hline
\end{tabular}

rows after 3 plant elimination from above and below of each plot. Tubers were manually harvested when about $70 \%$ of stems were fully desiccated. Tubers which were greened, misshapen or displayed pathological damage were classed as unmarketable, as well as those with weights lower than $20 \mathrm{~g}{ }^{18}$

Tuber nitrogen abundance was analyzed from a representative sample of at least 20 marketable tubers, of uniform size and disease-free, per replicate. The tubers were washed, dried with tissue paper, weighed, diced and blended in a mixer. Finally, an amount of the obtained batter was freeze-dried and stored at $-20^{\circ} \mathrm{C}$ until nitrogen calculation and total protein content analysis. ${ }^{19}$

The content of vitamin $\mathrm{C}$ was determined by the 2, 6 dichlorophenolindophenol colorimetric method. For this purpose, $100 \mathrm{~g}$ of raw tubers were mixed with $50 \mathrm{~mL}$ of $8 \%$ acetic acid and $50 \mathrm{~mL}$ of $3 \%$ metaphosphoric acid then the mixture was convulsed and strained. Then, $10 \mathrm{~mL}$ of DCPIP-treated solution was titrated to form a glycolic pink. Finally, the amount of vitamin $\mathrm{C}$ was reported as $\mathrm{mg} . \mathrm{kg}$ fresh weight $^{-1} .^{20}$

To measure the protein content the following equation was used $^{21}$ :

\section{Protein percent $=6.25 \times$ Nitrogen percent}

For this purpose, the amount of the nitrogen of the tubers was measured by the Kjeldahl method. To measure nitrate, the sulfosalicylic acid method was used with spectrophotometer apparatus at $410 \mathrm{~nm}$ wavelength. To do so, the device was previously calibrated with a blank solution of zero and standard specimens prepared by the device. Then, the equation of the number of readings was obtained from the spectrophotometer and nitrate concentration in standard solutions.
To measure the NR activity, $1 \mathrm{~cm}$ leaf discs (approx. 100 $\mathrm{mg}$ f. wt) were collected between 9 and 10 am and were kept on liquid nitrogen flask. The NR activity in leaf extracts was measured as described by Hageman and Hucklesby. ${ }^{22}$ Test tubes containing $0.1 \mathrm{~mL}$ phosphate buffer $(\mathrm{pH}=7.5,1 \mathrm{M})$, $0.1 \mathrm{~mL} \mathrm{NADH}, 0.2 \mathrm{~mL}$ of potassium nitrate $(0.1 \mathrm{M}), 0.2 \mathrm{~mL}$ distilled water and $0.1 \mathrm{~mL}$ of enzyme extract were placed in a bath at $27^{\circ} \mathrm{C}$ for 20 minutes. The reaction was stopped by the addition of $1 \mathrm{~mL}$ of sulfanilamide ( $1 \mathrm{~g}$ in $100 \mathrm{~mL}$ of normal chloride acid). After 5 minutes, $1 \mathrm{~mL}$ of $\mathrm{N}$-(1-Naphthyl) ethylenediamine dihydrochloride $(0.01 \% \mathrm{w} / \mathrm{v})$ was added and after 5 minutes, the samples were centrifuged at $2920 \mathrm{~g}$ for 15 minutes at $2^{\circ} \mathrm{C}$. Then the absorption change curve was read at $540 \mathrm{~nm}$ using a spectrophotometer and the activity of the NR enzyme was reported as $\left(\mu \mathrm{mol} \mathrm{NO}_{2} \cdot \mathrm{h}^{-1} \cdot \mathrm{g} \mathrm{FW}^{-1}\right){ }^{22}$

\section{Results}

Tuber Yield

A significant effect of fertilizer type on tuber yield was observed for both regions $(P<0.01)$ (Table 4$)$. Results also showed that potato yields ranged from 25.7 to 64.1 ton.ha ${ }^{-1}$ in Khorramabad and 21 to 58.9 ton.ha $^{-1}$ in Azna. In general, the mean tuber yield in Khorramabad was higher compared to Azna (43.7 and 38.9 ton. ha $^{-1}$ respectively) (Table 5). In both regions, there was an increase in tuber yield with 700 $\mathrm{kg}$ urea fertilizer.ha ${ }^{-1}$ corresponding to maximum tuber yield (Table 5).

\section{Nitrate Reductase Activity}

Based on the results, the NR enzyme activity was significantly different among the experimental regions and also the types of fertilizer (Table 4). In this regard, the activity of the NR enzyme measured in Khorramabad was higher compared to

Table 4. Resulting From ANOVA, for All the Studied Variables

\begin{tabular}{|c|c|c|c|c|c|c|}
\hline S.O.V & df & Tuber Yield & Vitamin C & Crude Protein & Tuber Nitrate & Nitrate Reductase Activity \\
\hline Region (R) & 1 & $368.7^{* *}$ & $56.8^{* *}$ & $0.25^{* *}$ & $57.6^{\mathrm{ns}}$ & $0.0053^{* *}$ \\
\hline Block & 4 & 5.5 & 5.47 & 0.13 & 12.8 & 0.00071 \\
\hline Fertilizer type (FT) & 10 & $957.5^{* *}$ & $80.7^{* *}$ & $0.91^{* *}$ & $21360^{* *}$ & $0.022^{* *}$ \\
\hline $\mathrm{FT} \times \mathrm{R}$ & 10 & $0.78^{\mathrm{ns}}$ & 0.24 & $0.0025^{\text {ns }}$ & $13.5^{\text {ns }}$ & 0.00006 \\
\hline Error & 40 & 4.62 & 1.55 & 0.0086 & 41.4 & 0.0002 \\
\hline $\mathrm{CV} \%$ & & 5.2 & 6.56 & 5.33 & 4.94 & 7.5 \\
\hline
\end{tabular}

Note: ns and ${ }^{* *}$ show non-significant and significant at $1 \%$ probably level, respectively.

Table 5. Influence of Place of Growing on Nitrate Reductase Activity, Crude Protein and Vitamin C of Tuber

\begin{tabular}{lccc}
\hline Region & Nitrate Reductase Activity $\boldsymbol{\mu m o l ~ N O}_{2} \cdot \mathbf{h}^{-1} \cdot \mathbf{g F W} \mathbf{- 1}^{-1}$ & Protein of Tuber \% & Vitamin C mg.100 g. tuber $^{-1}$ \\
\hline Azna & $0.19 \mathrm{~b}$ & $10.43 \mathrm{~b}$ & $19.8 \mathrm{a}$ \\
Khorramabad & $0.21 \mathrm{a}$ & $11.25 \mathrm{a}$ & $38.9 \mathrm{~b}$ \\
\hline
\end{tabular}

Means followed by similar letters are in each column have not significantly different. 
Azna (Table 5). In general, the activity of the NR enzyme was lower in the urea fertilizer compared to the poultry manure. Also, the highest NR activity in both sites was observed using $10304 \mathrm{~kg}$ poultry manure.ha- $\mathrm{H}^{-1}\left(200 \% \mathrm{~N}_{\mathrm{b}}\right)$.

\section{Percentage of Protein in the Tuber}

According to results, the mean protein percentage of tubers in the Khorramabad region was significantly higher than that of Azna city. In both experimental sites, the highest percentage of protein in the tuber was related to the high amounts of urea fertilizer, although there was no significant increase in the amount of protein at higher levels of nitrogen (Table 6).

\section{Tuber Nitrate}

The results have revealed that the nitrate content of tuber was influenced by the urea and poultry manure (Table 5). In both experimental sites, the high nitrate content of the tuber was followed by the high consumption of urea fertilizer. Although there was high nitrate accumulation in tubers similar to the urea fertilizer in the large amounts of poultry manure consumption approximately, the nitrate accumulation trend was moderated compared to the urea fertilizer (Table 6). Accordingly, the results of the present study show a significant difference of NR enzyme activity between urea fertilizer and poultry manure in both Khorramabad and Azna regions (Table 4). In general, in both places the tubers which were grown under poultry manure have lower accumulated nitrate amounts compared to the chemical $\mathrm{N}$ source ones (Table 6).

\section{Vitamin C of the Tuber}

Results show that site and nitrogen sources have a significant effect on the content of tubers vitamin C (Table 4). Between the 2 studied regions, the produced tubers of Azna (19.8 mg in $100 \mathrm{~g}$ tuber) contained more vitamin $\mathrm{C}$ compared to the tubers from Khorramabad (18 $\mathrm{mg}$ in $100 \mathrm{~g}$ tubers) (Table 5). In addition, the results showed that in terms of the vitamin C content, potato tubers grown by chicken manure had a relative superiority (Table 6).

\section{Discussion}

Tuber Yield

Higher potato yields resulting from the application of nitrogen can be attributed to an increases in the leaf area and a lengthening of the duration of canopy cover thus extending the period of light interception. ${ }^{23}$ On the other hand, decreasing the tuber yield followed by high level consumptions of fertilizer has been attributed to increasing assimilate and water consumption through higher biomass production and also intra-plant competition. In addition, it also seems that one of the main reasons for tuber yield decline may be a result of the delay of tuber maturity. ${ }^{24}$ One of the important results from this experiment was the production of tuber yield approximately close to urea fertilizer yields by the consumption of $10304 \mathrm{~kg}$ poultry manure.ha- ${ }^{-1}$ especially in Azna. Similar to our findings, some researchers have also reported acceptable tuber yield production by poultry manure. ${ }^{3,25}$ It may be imperative considering environmental pollutions, threats to human health and providing a model for the deployment of a sustainable production system.

\section{Nitrate Reductase Activity}

$\mathrm{NR}$ is a key enzyme for nitrogen metabolism in plants. In addition, NR has been proposed as an important enzymatic source of nitric oxide (NO). ${ }^{12}$ Similar our results there were reported the higher amount of NR activity in tomatoes when using vermicompost fertilizer treatments. ${ }^{26}$ It has been suggested that water, carbohydrates and photosynthesis rates play a role in the expression of NR enzyme gene. Thus, improving NR activity in organic sources of nitrogen has been attributed to their effect on the photosynthesis rate and plant water accessibility. Also, the decreasing of nitrate density in organic sources of nitrogen supply is effective in reducing the inhibitory effect of NR activity, as it is believed that the rate of NR enzyme activity gradually decreases when plants subject to the nitrate-rich environment. ${ }^{26}$ This is due to the fact that nitrate is an important signal for molecular, metabolic, and physiological responses. In fact, nitrate contributes signals

Table 6. Effect of Urea Fertilizer and Poultry Manure on Nitrate Reductase and Some Potato Tuber Composition

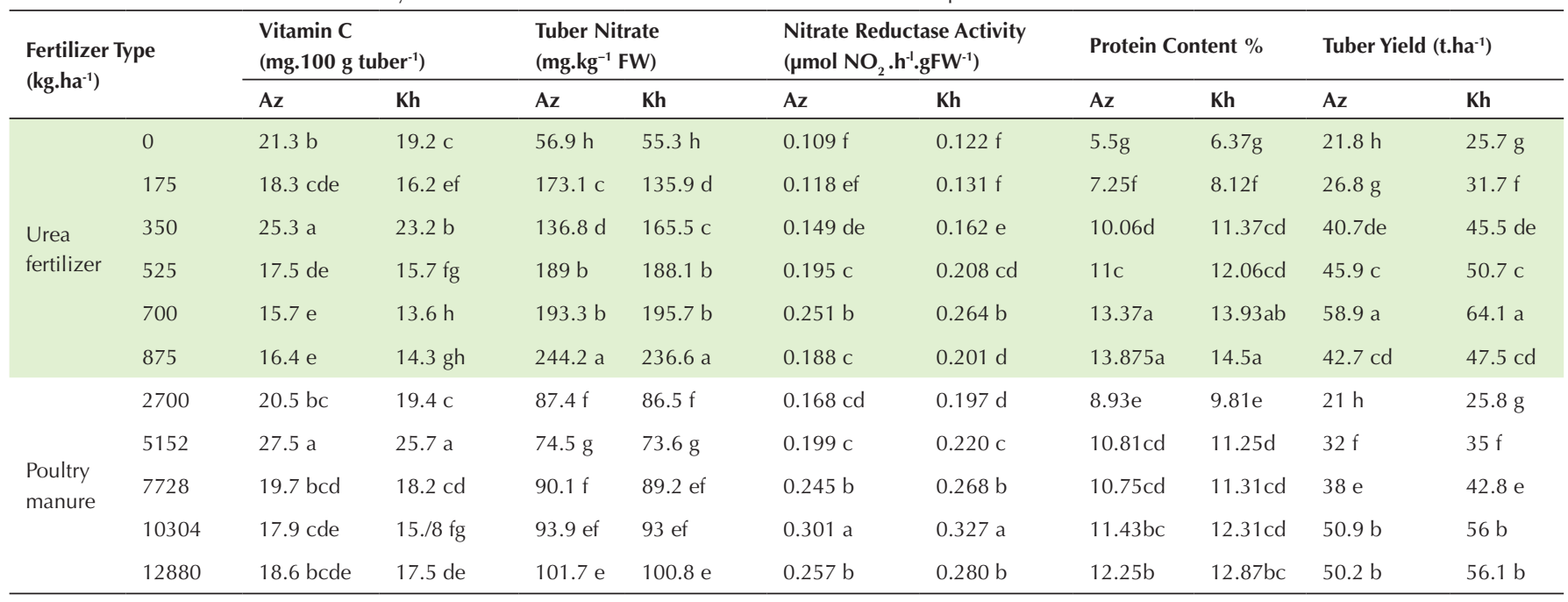

Means followed by similar letters are in each column have not significantly different.

Abbreviations of $\mathrm{Kh}$ and $\mathrm{Az}$ stand for Khorramabad and Azna respectively. 
that modulate the expression of nitrate assimilation genes. ${ }^{12}$ Furthermore, it has been accepted that some organic manure compositions, such as humic acid and fulvic acids, have an effect on molecular expression and proteins involved in nitrate uptake. Because humic acid increase the soil acidity slightly by means of AtNRT 1:1 gene activation. ${ }^{27}$

\section{Percentage of Protein in the Tuber}

The positive relationship of tuber protein with nitrogen consumption along with no significant effect on higher values has also been reported by researchers. ${ }^{23,28}$ However, in contrast, it has been reported a decreasing in the protein content of the tuber as a result of an increase in nitrogen levels. ${ }^{14}$. The lower protein rate in Azna may be due to its lighter soil compared to Khorramabad, as nitrogen uptake is less in lighter soils. Although the total protein content of grown tubers in poultry manure was significantly lower than that in the chemical grown tuber, it is revealed that the protein quality according to peptide composition is higher in the organically grown crops due to its nutritional value. ${ }^{29}$

\section{Tuber Nitrate}

Increasing the nitrate accumulation in potato tubers has also been reported by other researchers. ${ }^{30-32}$ It is believed that using high amounts of nitrogen-containing fertilizers in the soil, will result in increasing the absorption of nitrate by roots. This is while its reduction and assimilation does not increase in the same proportion, which results in nitrate accumulation in the plant's tissues. Probably one of the conceivable reasons for the difference in nitrate accumulation in the tubers produced from the urea fertilizer and poultry manure in this study can be attributed to the difference in the activity of NR enzyme. Also, the difference in nitrate accumulation can be attributed to the difference in nitrogen abandonment trend between organic and chemical supply sources. Nitrogen fertilization encourages accumulation of nitrate in plant tissues because the nitrogen uptake accelerates its reduction. When nitrate uptake excess the actual requirement, it is stored as free nitrate in the vacuole and can be remobilized subsequently when nitrogen supply is insufficient to meet the demand. ${ }^{10}$ Nitrate accumulation in plant tissues is caused by increasing the amount of nitrate by chemical fertilizer and mineralization of soil organic matter, and also the reduced availability of assimilate. Therefore, the higher accumulation of nitrate will accrue compare to manure. Furthermore, the poorly controlled flux of soil nitrogen resulting from active mineralization of organic matter may lead to excessive accumulation of nitrate in plants. ${ }^{10}$

On the other hand, an increase in the amount of nitrate in the tuber may be due to the lack of sufficient opportunity to convert the absorbed nitrate into proteins by the tuber. When the plant grows under abnormal conditions, such as overconsumption of nitrogen fertilizer, the protein production is reduced and as a result, nitrogen is accumulated in the plant, as a non-protein form (nitrate). ${ }^{10,33}$ However, some researchers have considered the role of genetics in nitrate accumulation more important and believe that the differences are more dependent on the capacity of the cultivars in the accumulation of nitrates. ${ }^{9}$

It is known that organic fertilizers with slowly or moderately available nitrogen compared with chemical ones lead to lower nitrate accumulations in vegetables. ${ }^{19}$ No sample from both nitrogen sources exceeded, however, the nitrate limit of 200 mg. $\mathrm{kg}^{-1} \mathrm{FW}$ was proposed by some European countries, which is an important benefit in the context of human health. ${ }^{34}$

\section{Vitamin C of the Tuber}

Similar to the present study, lower contents of vitamin $C$ is followed by the use of higher levels of nitrogen. ${ }^{15}$ It has been shown that the crop production system significantly affects the vitamin $\mathrm{C}$ content. Many studies have demonstrated that the chemical composition of tubers, such as vitamin $\mathrm{C}$ in tubers from organic farming are better than other systems. ${ }^{4,15,29,35}$

The higher content of vitamin C in Azna may be due to the lighter soil of this site compared to Khorramabad. ${ }^{15}$ However, the differences between the chemical compositions of tubers in experimental places can be attributed to different climatic conditions during the growing season such as the amount of rainfall and temperature.

\section{Conclusions}

The results of the present study showed that excessive accumulation of nitrate in the tubers, which is considered as an undesirable characteristic, occurred when using too much nitrogen. Therefore, the excess use of nitrogen fertilizer not only increases the cost of production but also reduces the quality of the product, i.e. increasing the nitrate accumulation in the tubers, which is harmful to the farmer, consumer and the environment in every respect. A concern exists in regards to the similarity of the tuber yields between the 2 nitrogen resources of chemical fertilizer with organic fertilizer in order to achieve food security and an efficient and sustainable food chain. However, using poultry manure as an organic nitrogen source improves some compounds such as vitamin $\mathrm{C}$ and reduces the risk of nitrate threats. The excessive use of poultry fertilizer can also result in the excessive accumulation of nitrate in the potato tubers. Thus, the belief that the use of organic fertilizers, at any level, would not cause any problem for the health of products is definitely incorrect.

Authors' Contributions

All authors equally contributed to the present study.

\section{Conflict of Interest Disclosures}

The authors declare they have no conflicts of interest.

\section{References}

1. Panhwar QA, Ali A, Naher UA, Memon MY. Fertilizer Management Strategies for Enhancing Nutrient Use Efficiency and Sustainable Wheat Production. In: Chandran S, Unni MR, Thomas S, eds. Organic Farming. Woodhead Publishing; 2019:17-39. doi:10.1016/B978-0-12-813272-2.00002-1.

2. Ladha JK, Pathak H, Krupnik TJ, Six J, van Kessel C. Efficiency of fertilizer nitrogen in cereal production: retrospects and prospects. Advances in Agronomy. 2005;87:85-156. doi:10.1016/S00652113(05)87003-8.

3. Oustani M, Halilat MT, Chenchouni H. Effect of poultry manure 
on the yield and nutriments uptake of potato under saline conditions of arid regions. Emir J Food Agric. 2015;27(1):106-120. doi:10.9755/ejfa.v27i1.17971.

4. Lombardo S, Pandino G, Mauromicale G. The effect on tuber quality of an organic versus a conventional cultivation system in the early crop potato. J Food Compost Anal. 2017;62:189-196. doi:10.1016/j.jfca.2017.05.014.

5. Behbood M, Golchin A, Besharati H. The effects of soil compaction on tuber yield and quality and uptake of nutrients by potato plant (Solanum tuberosum L.). Journal of Water and Soil. 2012;26(1):1119. [Persian].

6. Anonymous. Statistics of agriculture. Iran: Ministry of Agriculur Jahad, 2016.

7. Camargo DC, Montoya F, Córcoles JI, Ortega JF. Modeling the impacts of irrigation treatments on potato growth and development. Agric Water Manag. 2015;150:119-128. doi:10.1016/j. agwat.2014.11.017.

8. Sharifi M, Hajabbasi MA, Kalbasi M, Mobli M. Root morphological characteristics and nitrogen uptake of eight potato (Solanum tuberosum L.) cultivars. Journal of Water and Soil Science. 2005;9(1):181-192. [Persian].

9. Gorenjak AH, Urih D, Langerholc T, Kristl J. Nitrate content in potatoes cultivated in contaminated groundwater areas. J Food Res. 2013;3(1):18-27. doi:10.5539/jfr.v3n1p18.

10. Anjana $S U$, Iqbal M. Nitrate accumulation in plants, factors affecting the process, and human health implications. A review. Agron Sustain Dev. 2007;27(1):45-57. doi:10.1051/agro:2006021.

11. Chung HJ, Li XQ, Kalinga D, Lim ST, Yada R, Liu Q. Physicochemical properties of dry matter and isolated starch from potatoes grown in different locations in Canada. Food Res Int. 2014;57:89-94. doi:10.1016/j.foodres.2014.01.034.

12. Chamizo-Ampudia A, Sanz-Luque E, Llamas A, Galvan A, Fernandez E. Nitrate reductase regulates plant nitric oxide homeostasis. Trends Plant Sci. 2017;22(2):163-174. doi:10.1016/j. tplants.2016.12.001.

13. Love SL, Pavek JJ. Positioning the potato as a primary food source of vitamin C. Am J Potato Res. 2008;85(4):277-285. doi:10.1007/ s12230-008-9030-6.

14. Rop $\mathrm{O}$, Buňka $F$, Valášek $P$, Kramářová $D$. The influence of nitrogen fertilization on starch content and amino-acid composition of very early-harvested potato tubers. Acta Fytotech Zootech. 2009;12(3):72-75

15. Zarzynska K. Chemical composition of potato tubers in relation to crop production system and environmental conditions. Journal of Agricultural Science and Technology B. 2013;3(10B):689.

16. Kirk PL. Kjeldahl method for total nitrogen. Anal Chem. 1950;22(2):354-358. doi:10.1021/ac60038a038.

17. Peters J, Combs S, Hoskins B, et al. Recommended Methods of Manure Analysis. Madison, WI: University of Wisconsin Cooperative Extension Publishing; 2003.

18. Grange G. United States Standards for Grades of Potatoes. Washington, DC: US Department of Agriculture Food Safety and Quality Service; 1972.

19. Lombardo S, Lo Monaco A, Pandino G, Parisi B, Mauromicale G. The phenology, yield and tuber composition of 'early' crop potatoes: A comparison between organic and conventional cultivation systems. Renew Agric Food Syst. 2013;28(1):50-58. doi:10.1017/S1742170511000640.
20. Emmerie A, Van Eekelen M. The chemical determination of vitamin $C$ with removal of interfering reducing and coloured substances. Biochem J. 1934;28(4):1153-1154. doi:10.1042/bj0281153.

21. Salo-Väänänen PP, Koivistoinen PE. Determination of protein in foods: comparison of net protein and crude protein $(\mathrm{N} \times 6.25)$ values. Food Chem. 1996;57(1):27-31. doi:10.1016/03088146(96)00157-4.

22. Hageman RH, Hucklesby DP. Nitrate reductase from higher plants. Methods Enzymol. 1971;23:491-503. doi:10.1016/S00766879(71)23121-9.

23. Gao X, Li C, Zhang M, Wang R, Chen B. Controlled release urea improved the nitrogen use efficiency, yield and quality of potato (Solanum tuberosum L.) on silt loamy soil. Field Crops Res. 2015;181:60-68. doi:10.1016/j.fcr.2015.07.009.

24. Muleta HD, Aga MC. Role of nitrogen on potato production: a review. J Plant Sci. 2019;7(2):36-42. doi:10.11648/j. jps.20190702.11.

25. Rees HW, Chow TL, Zebarth B, et al. Impact of supplemental poultry manure application on potato yield and soil properties on a loam soil in north-western New Brunswick. Can J Soil Sci. 2014;94(1):49-65. doi:10.1139/CJSS2013-009.

26. Márquez-Quiroz C, López-Espinosa ST, Sánchez-Chávez E, García-Bañuelos ML, de la Cruz-Lázaro E, Reyes-Carrillo JL. Effect of vermicompost tea on yield and nitrate reductase enzyme activity in saladette tomato. J Soil Sci Plant Nutr. 2014;14(1):223231. doi:10.4067/S0718-95162014005000018.

27. Canellas LP, Olivares FL, Aguiar NO, et al. Humic and fulvic acids as biostimulants in horticulture. Sci Hortic. 2015;196:15-27. doi:10.1016/j.scienta.2015.09.013.

28. Jamaati-e-Somarin SH, Tobeh A, Hashemimajd K, et al. The effect of plant density and various levels of nitrogen on protein percent, yield and nitrate accumulation in potato tuber. Electronic Journal of Crop Production 2009;2(3):151-164. [Persian].

29. Rembiałkowska E. Quality of plant products from organic agriculture. J Sci Food Agric. 2007;87(15):2757-2762. doi:10.1002/jsfa.3000.

30. El-Sayed SF, Hassan HA, El-Mogy MM. Impact of bio-and organic fertilizers on potato yield, quality and tuber weight loss after harvest. Potato Res. 2015;58(1):67-81. doi:10.1007/s11540-0149272-2.

31. Eleroğlu H, Korkmaz K. Effects of different organic fertilizers on the yield and quality traits of seed potato cultivars (Solanum tuberosum L.). Turkish Journal of Agriculture-Food Science and Technology. 2016;4(7):566-578. doi:10.24925/turjaf.v4i7.566-578.711.

32. Tein B, Kauer K, Eremeev V, Luik A, Selge A, Loit E. Farming systems affect potato (Solanum tuberosum L.) tuber and soil quality. Field Crops Res. 2014;156:1-11. doi:10.1016/j.fcr.2013.10.012.

33. Döring TF, Brandt M, Heß J, Finckh MR, Saucke H. Effects of straw mulch on soil nitrate dynamics, weeds, yield and soil erosion in organically grown potatoes. Field Crops Res. 2005;94(2-3):238249. doi:10.1016/j.fcr.2005.01.006.

34. Hord NG, Conley MN. Regulation of dietary nitrate and nitrite: balancing essential physiological roles with potential health risks. In: Bryan NS, Loscalzo J, eds. Nitrite and Nitrate in Human Health and Disease. Cham: Springer International Publishing; 2017:153162. doi:10.1007/978-3-319-46189-2_12.

35. Lairon D. Nutritional quality and safety of organic food. A review. Agron Sustain Dev. 2010;30(1):33-41. doi:10.1051/agro/2009019. 